\title{
QUALITATIVE STUDY ON EFFECTIVE TELEHEALTHEDUCATIONAL METHOD CHRONIC OBSTRUCTIVE PULMONARY DISEASE (COPD) IN MOJOKERTO INDONESIA
}

\author{
RIFAATUL LAILA MAHMUDAH ${ }^{1}$, EKA DIAH KARTININGRUM ${ }^{2}$, ZULLIES IKAWATI ${ }^{3}$, DJOKO WAHYONO ${ }^{3}$ \\ 1Public Health Program, Sekolah Tinggi Ilmu Kesehatan Majapahit, Mojokerto 61364, Indonesia, ${ }^{2}$ Nursing Program, Sekolah Tinggi Ilmu \\ Kesehatan Majapahit, Mojokerto 61364, Indonesia, ${ }^{3}$ Department of Pharmacology and Clinical Pharmacy, Faculty of Pharmacy \\ Universitas Gadjah Mada, Sekip Utara Yogyakarta, 55281, Indonesia \\ Email: rifaatul@gmail.com \\ Received: 14 Feb 2019, Revised and Accepted: 11 Apr 2019
}

\section{ABSTRACT}

Objective: To find the effective method of telehealth for COPD patients through focus group discussions (FGD) health professional and COPD patients.

Methods: Focus group discussions, the materials of FGD consist of educational contents, telehealth media, and education schedule. Discussions involving 11 participants, six medical professionals ( 2 medical doctors and 4 pharmacists), and 5 patients with COPD in four Hospital in Mojokerto.

Results: According to the health professional and COPD patients educational materials necessary for patients with COPD is knowing disease (such as symptoms, causes, transmission, and prevention), how to use an inhaler, and treatment of COPD from medication to a healthy lifestyle. The educational materials should be showing in television available at the patient's waiting room in the hospital.

Conclusion: It is expected that repeated education will increase patient's knowledge on COPD as well as their health status.

Keywords: Education, Telehealth, Chronic obstructive pulmonary disease (COPD), Focus group discussions (FGD)

(C) 2019 The Authors. Published by Innovare Academic Sciences Pvt Ltd. This is an open-access article under the CC BY license (http://creativecommons.org/licenses/by/4.0/) DOI: http://dx.doi.org/10.22159/ijcpr.2019v11i3.34088

\section{INTRODUCTION}

Chronic obstructive pulmonary disease (COPD) is a chronic disease marked with limited air flow worsening progressively and is related with abnormal inflammation of lungs against dangerous particles or gases [1]. Complications often taking place on COPD patients are limited activities, weight loss, increasing risk on cardiovascular diseases, osteoporosis [2], pneumonia [3], cor pulmonale, pneumothorax, pulmonary hypertension [4], even depression [5]. COPD can also increase the direct cost up to USD 18 million and indirect cost up to USD 14.1 million in COPD countermeasure in Europe [2].

The purpose of COPD the rapyisto improve the chronic obstructive condition, to prevent and overcome acute excacerbation, to decrease disease prognosis, to improve patients physical and psychological condition, as well as to decrease mortality rate $[1,6]$. The effectiveness of COPD patients medication is heavily influenced by their compliance [7], however, unfortunately, COPD patients' compliance could be considered low $(<50 \%)$ this is due to lacking of monitoring optimization on patients' medicine intake [8]. Compliance can affect the clinical outcome and patients' life quality [9].

Patient's education program can be an important strategy in supporting them to achieve success in chronic disease treatment management $[10,11]$, but COPD education is something new and has not yet been developed compared with other chronic diseases like diabetes and asthma [12]. Technology is a means to support the delivery of educational material in order to be easily accepted by patients. According to Nguyen (2013), dyspnea education based on the Internet to COPD sufferers will increase their compliance compared with that of conventional education [13].

Latest technology and services that can be implemented to support the giving of education to COPD patients are telehealth [14]. Research about telehealth on COPD patients has been conducted in various countries [15-18]. Telehealth is the utilization of technology in the field of information and communication to send and deliver health services which can be done remotely. Educational method applied in Indonesia is mostly observational learning in nature, such as giving the lecture, discussion, modules, and role play. Those all methods aim to help subjects in understanding information and translate it into actions [19]. Telehealth could also be a compatible solution in delivering education in developing countries because it requires low cost and low bandwidth. Telehealth can also increase the quality of service by supporting better chronic disease management, best practical applications, knowledge improvement and skill development in giving service as well as treatment condition improvement [20]. For COPD patients, telehealth could function to monitor vital signs and/or biological health data, to monitor symptoms development, medication, or final result of nonbiological examination, to provide information as well as other supporting services, and communication between patients and medical professionals [21] which will raise patients' concern on their medication that it affects patients' self-management [22].

In supporting the role of information and education giver on patients, a method suitable and easily accepted by patients is required. One of the results of the research suggests that counseling intervention and the delivering of traditional counseling is not effective in terms of long term change [23]. Based on those aforementioned backgrounds telehealth program is required as a new means for COPD patients to increase health services. This research aimed to find the effective application of telehealth educational method for chronical obstructive pulmonary disease (COPD) out-patients in Mojokerto through focus group discussions (FGD) involving relevant medical professionals and COPD patients.

\section{MATERIALS AND METHODS}

\section{Research design}

This research is qualitative research. Data collection used focus group discussions (FGD). The discussion was about the most suitable educational method with telehealth in four hospitals in Mojokerto. Both groups (medical professionals and COPD patients) would discuss in FGD by sharing each other to get feedback on initial concepts. Program and instrument framework which was used was developed through FGD, a brainstorming session in which all 
participants can utter their ideas openly regarding certain things that each participant will reach an agreement. FGD participants are personnel's views as having ability and skill in the researched field that they will give appropriate ideas.

\section{Population and sample}

Data collection in this research involved two respondent groups' i.e. medical professional and COPD patients. Research respondents from medical professionals comprised of medical doctors and pharmacists. Research population from medical professionals were those who were directly involved in COPD outpatient treatment in the hospital's pulmonology. Samples from medical professionals wiling to get involved within the research and have worked for at least $1 \mathrm{y}$. While samples from COPD patients were COPD patients hospitalized in hospitals where the research took place willing to get involved in the research and met the inclusion and exclusion criteria.

\section{Inclusion and exclusion criteria}

Inclusion criteria are: [1] had been an outpatient in that hospital for at least $1 \mathrm{y},(2)$. aged $>40$ y (1). While exclusion criteria are [21]: (1.) Patients requiring manual ventilation; (2.) Patients having serious comorbidity (renal, liver, and heart failure); (3.) Patients having the malignant disease, and (4.) Diseases or other conditions disabling patients to participate (like dementia or delirium). Sampling technique in this research of FGD stage was purposive sampling, i.e. sample collection is adjusted with certain purposes. Sample stipulation at this stage are in line with inclusion and exclusion criteria.

\section{Data collection method and data analysis}

Data collection process was done by preparing tools such as FGD guidelines, writing tools, and recorder. Infrastructures prepared is a comfortable room equipped with a whiteboard. The conduct of FGD aimed to discuss the model framework as well as contents, processes, and guidelines that will be the reference in the implementation of telehealth program regarding COPD. Researcher prepared concepts and guidelines draft. Discussion would be started with open-ended questions which would enable respondents to give input with explanation, assisted by facilitators as moderator. Open-ended questions included:

1. What materials should be given to COPD telehealth program?

2. What media do you think is effective and easily reachable to provide information on COPD patients?

3. When and how often should telehealth education be given to COPD patients?

FGD was conducted with a duration of $120 \mathrm{~min}$. After all the data is collected, the discussions were transcribed and the transcripts were analyzed.

\section{RESULTS}

Based on FGD conducted with 11 participants, consisting of 6 personnels of medical practitioners (2 medical doctors and 4 pharmacists), and 5 COPD patients in four hospitals in Mojokerto.

\section{Materials given in COPD telehealth program}

Materials deemed by the respondents necessary to be given in COPD patient's education are regarding:

1. Understanding COPD. Most medical professionals agreed to share knowledge regarding COPD, starting from its cause, prognosis of its worsening, and symptoms accompanying it.

"yes, at least people know what COPD is....... that's why ....... they will know when they have to visit the doctor instead of just ignoring it until they suffer from accute shortness of breath that they go to the doctor to check it [(medical doctor), RS C]"

For ordinary people, it can be added that one of the symptoms of COPD is prolonged coughing, because people think that it is commonly caused by dust and riding motorcycle too often [(medicaldoctor), RS A]
"There are many factories in Mojokerto that the people here should be more alert. we can add the way how to anticipate from getting infected by COPD [\{Pharmacist), Hospital D]"

This is also supported by respondent's opinion from COPD patients group because most patients suffering from COPD for years also haven't fully understood their disease.

"For now, I have already known better. Well, if you study at school you can search on the Internet about it. but at least ordinary people know what COPD is. How could one get it, what are the causes. Can it be cured, or whether it is infectious or not? [(Patient), Hospital C]"

“.... Next time, it can be faster, When one knows that they have these symptoms they should get to the doctor asap [(Patient1), Hospital A]"

2. How to use an inhaler. Input for this material was from medical professionals i.e. consultant taking care of COPD patients and pharmacist playing the role in giving counseling to COPD patients.

“COPD patients receive inhaler just like asthma patients, it is better that they are taught how to use the inhaler properly, the type of the inhaler to be given will be adjusted with what stocks we have most here, in the hospital. So, pharmacist's or doctor's task in explaining will be easier. [(Pharmacist), Hospital A]"

"Sometimes patient complains if we keep giving them the same medicine. and they still suffer from shortness of breath. However, when they are asked about how they use it turns out it is not properly done that they don't get the maximum result, e. g.: they don't shake it before using, they exhale it directly without being inhaled and hold for 5 seconds [(Pharmacist), Hospital C].

".... And their reason is so common every time they get to the pharmacy and ask how to use it, they forget it... Or else, when they pay next visit they will ask, "This medicine you gave us yesterday, I just leave it, just don't know how. (still neatly packaged) [(Doctor), Hospital A]"

This is supported with the respondent's opinion from the COPD patient group, they felt it difficult when using the inhaler.

"First time I got the medicine from the doctor, in that nice package, I was hesitated though I was told on how to use it, so I just left it there.... I'm getting old, I forget easily .... So, I took my child me, they understood better when explained by the doctor [(Patient1), Hospital A]"

"I understood what that lady at purple counter, but when I got home turned out I forgot which one will sound click when presed. I saw the paper and it's written in English. [(Patient2), Hospital A]"

"Well at least patient will understand how to use those neatly and nicely packaged medicine.... to be understood easily [(Patient), Hospital D]"

3. Concerning general pharmacological and non-pharmacological therapy on COPD.

According to medical professionals, the patient needs to know the outline of the benefit of medicines usually prescribed. It is expected that it will help to increase patients' health status.

"Patients rarely ask about medicines, but it's an important thing should patients understand the general picture of their medication such as what and how does the disease itself develop since COPD is a sort of damage on one's lungs, thus it has no possibility of full recovery [(Doctor), Hospital A]"

"Because COPD patients are expected to pay regular visit. Some complained that they are tired of taking medicined and didn't understand the benefit of the medicines given. (Pharmacist), Hospital D]"

"Few other things like physical exercise must be included into COPD educational materials because that can improve patient's health status [(Doctor), Hospital C]"

Even though many COPD patients felt that they had already had enough information, turned out they didn't have a proper understanding of it. 
My doctor gave me a bunch of medicines, it confuses me. Maybe he will add more medicines when I come for follow-up visit [(Patient 2), Hospital A]"

When taking medicine, I took everything the gave me on the counter, I knew that this one is for shortness of breath and this one is antibiotics (must be finished), and the another one should be taken when I got the fever. [(Patient 2), Hospital C]"

"This is sprayed (pointing to MDI inhaler, without understanding the steps) [(Patient 1), Hospital A]"

"I took the medicine as per the writing attached on the medicines [(Patient), Hospital D]"

\section{Media used in COPD educational program with telehealth}

Media which is suitable for COPD patients in Mojokerto hospital is by using video broadcasted to televisions located in an outpatient ward waiting room and pharmacy counter waiting room, according to medical professional's respondents. The opinions are as follows:

"This is an age of the Internet, people will search on Google whatever they need to know. However, most COPD sufferers are elderly people. Maybe some have internet access, if they live in urban areas. But those who live in Trawas, the internet signal is poor there. Only young people like streaming. [(Doctor), Hospital C]"

"We have a TV in the hospital, in front of the waiting room, maybe you can display some program like public service advertisement, that might be much better because people will feel like watching film and it can be repeated [(Pharmacist), Hospital A]"

"It might be better if displayed on TV, though it is difficult to get into national TV. At least when the patient or their families wait, they get new knowledge [(Pharmacist), Hospital C]"

For educational media respondents, telehealth by using television in the waiting room is also interesting.

"Here, just for getting medicine, one might wait from 9 am to $2 \mathrm{pm}$. If it is crowded, it can be until $4 \mathrm{pm}$. When waiting for a long time like that, maybe the television can be more useful. You know, it sometimes turned on, some other times turned off. Maybe something that can increase our knowledge can be displayed there [(Patient 1), Hospital A]"

"I'm now an old guy. If you ask me to read, maybe I will read it better if the images are good, but still I need glasses to read [(Patient), Hospital D]"

"The age is so advanced now. Nowadays, every phone is a smartphone. But I don't use such phone. For me, making phone call and sending SMS is enough. I don't understand about the Internet whatsoever. It confuses me. [(Patient), Hospital B]"

While other methods like leaflet is considered not effective because of only a few people willing to read.

"We need brochures to be put in the reception, when patient is registering, though sometimes they don't read it [(Pharmacist), Hospital C]"

Initially, one of the COPD patient respondents suggested direct education material delivery because they think that information given face to face will be more comfortable.

"I feel more comfortable when they come to visit each of our house individually. The explanation will be clear and I will not be hesitated to ask. I can't ask a lot if I'm in the hospital. At home, I can have my wife or my children accompany me. So, in case I missed something, they still remember it. [(Patient 2), Hospital A]"

However, this idea is eventually denied by respondents from medical professionals because the number of medical workforces in the hospital is limited. Their abilities, number, and time are limited.

"It would be improbable to do like homecare, you know. our professionals are limited. We receive more than 1,000 prescriptions in a day, while we only have 4 professionals. It will be difficult to do one on one homecare. [(Pharmacist), Hospital A]"
"Besides lacking of workforces, we don't have much time either. It took 30 min from the patient's house to the hospital, my jobs in the hospital will be neglected if I do so [(Doctor), Hospital C]"

"We don't know whether we will get approval for home care to patient's house or not. If the hospital asks us to go for home care, we will be gladly doing it because we have clearance and facilities from the hospital [(Pharmacist), Hospital B]"

\section{Frequency and duration of the delivery of telehealth education to COPD patients}

According to medical professionals, it is preferred that the delivery of education to COPD patients is adjusted by follow-up visit frequency i.e. once every two weeks.

"COPD patients usually come to the hospital once every two weks for a follow-up visit, or once in a month. So, I think it is better to give them the education materials when they come for a follow-up visit. They can get knowledge while waiting [(Pharmacist), Hospital A]"

"If they have been exposed to education materials more than 3 times, they would have understood [(Pharmacist), Hospital D]"

"The patient will truly understand. You know,. They come for follow up once every two weeks. If you only show the video once, it won't be enough to make them understand. Showing them the video 4-5 times will make it. [(Doctor), Hospital A]"

\section{DISCUSSION}

Education is an important thing in stable long term management of COPD [6]. The importance of health education to COPD patients among others is to increase the efficacy of health management besides health behavior, but this depends on the purposes of the health program [11]. According to Indonesian Pulmonologist Asociation (2011), the purposes of education to COPD patients among others are: [1] understanding disease cycle and its treatment [2] performing maximum treatment, [3] achieving optimum activities, and [4] improving life quality. A meta-analysis regarding pulmonary rehabilitation program on COPD patients could decrease dyspnea and fatigue, increase emotional function as well as patient's control on their condition [24].

\section{Materials given in COPD telehealth program}

Educational materials to be given to COPD patients include:

1. Concerning COPD itself. Detailing of education for COPD patients according to Stoilkova, Janssen, and Wouters (2013), are: initial identification and measures at the event of relapse, an action plan on independent treatment after relapse, physiological anatomy of normal lungs, the pathophysiology of COPD, and breathing strategy. This is also supported by Guidelines for Diagnosis and Management in Indonesia $[25,6]$.

COPD patients understanding of their disease, influenced by internal and external factors. Internal factors: (1.) Education, which can affect someone including their behavior concerning life pattern, especially in motivating them to participate in national development. Generally, the higher is one's education, the easier they receive information; (2.) Occupation; and (3.) Age, in which someone that has already been mature is more trusted than one that hasn't fully matured. It's a part of experience and maturity. While external factors include environment and socio-cultural factors which can affect the development and behavior of people or group of people and their attitude when receiving information [26].

2. How to use an inhaler. The benefit of knowledge and skill in using inhaler properly is that the medicine will be deposited maximally in lungs, while the improper way in using inhaler will lead to more problems such as oropharyngeal candidiasis or worsening condition needed to be taken care in the hospital [1]. It is strongly suggested that COPD treatment is done through inhalation [1]. An inhaler is a device used to give the medicine through inhalation. Inhaler delivery system is an important form of drug delivery device in the treatment, because it has benefit in delivering medicine directly into the respiratory system and has fewer side effects [27]. Drug working effect through inhalation depends on the depositing pattern of 
inhalation drug in the respiratory system, this is determined by the complex interaction between inhalation device, aerosol formulation, and the way how patient use the inhalation. Each type of inhaler has different instructions for use and requires different way in treating it, this could cause patient's mistake in using inhaler device which is originally designed to increase the easiness of usage in delivering optimum effects [28]. Inhaler's using in COPD patients will only be effective if the patient feels comfortable to use their inhalation properly. Improper inhaler technique decreases the delivering of medicine into the respiratory tract that it decreases the effectiveness of inhaler drug [29].

Research on the using of inhaler suggested that the absence of crystal clear instruction regarding how to use inhaler could lead to improper using technique. [30]. Most patients getting inhalation drug prescription did not use their inhaler properly. In a clinical study, as many as $90 \%$ of the patients used wrong techniques in using metered-dose inhalers (MDIs), diskus ${ }^{\circledR}$, danturbuhaler ${ }^{\circledR}[28]$.

3. Concerning pharmacological and non-pharmacological therapy to COPD patient. According to medical professionals, the patient needs to know the drugs used by COPD patients, i.e. their benefit, usage interval, possible side effects and how to overcome them, and how to store the drugs.

\section{Media used in COPD education program with Telehealth}

Fast and advanced development of information system technology can be utilized in increasing the effectiveness, efficiency, and quality of health service. One of which is the utilization of telehealth program. According to Scott et al. (2007), telehealth is defined as an application or utilization of information and communication technology to deliver health-related information and services. Basic concepts of the application of telehealth is due to the vast distance between medical professionals and patients [21, 31]. Thus, the utilization of telehealth shall ensure the continuation of the delivery of health services.

Educational media by using telehealth, according to the result of FGD, is video displayed on the television located in the waiting room. Education by using video is more effective than that of a leaflet, this is similar with the result of the research by Stellefsonetal. (2009) comparing educational technique by using DVD wo that of using pamphlete in countryside people of Alabama, USA. It suggested that COPD patients educated with DVD showed increasing lung function compared to that of pamphlets [32].

\section{Frequency and duration of the delivery of telehealth education to COPD patients}

It was agreed that the delivery of education is not only once because presumably, but the respondents also will not understand enough, hence it was planned that it will be done every time respondents come for a follow-up visit. It was assumed that the patient will be educated 4-5 times a month. Previous researches also conducted education several times.

\section{Research limitation}

a. The discussion did not involve COPD patient's family as supporting forces playing an important role in monitoring the treatment and COPD patient's condition every day. This research did not involve patient's family because FGD generally comprises of only 7-11 people, this would enable each individual to get an opportunity to express their opinion, as well as getting enough feedbacks from group members [33].

b. COPD patient's respondents were not classified based on their severity. This is due that the monitoring of COPD patients' severity requires spirometry examination [1], which is not available in Mojokerto hospitals.

\section{CONCLUSION}

According to medical professionals and COPD patients in hospitals inMojokerto, educational materials needed by COPD patients are concerning COPD itself, how to use an inhaler, and COPD treatment. It is better that those educational materials utilized television in pulmonology waiting room. It is also expected that through repeated education, COPD patient's knowledge and health status will increase.

\section{ACKNOWLEDGMENT}

Our deepest gratitude goes to the Yayasan Kesejahteraan Warga Kesehatan Kabupaten Mojokertoand Sekolah Tinggi Ilmu Kesehatan Majapahit supported us. A sense of gratitude is also conveyed to the director of RS Gatoel, RS Sakinah, RSUD Dr. Soekandar and RS Dr Wahidin Sudirohusodoin Mojokertofor the opportunity given to the researcher to do the research completely.

\section{AUTHORS CONTRIBUTIONS}

All the author have contributed equally

\section{CONFLICT OF INTERESTS}

\section{Declare none}

\section{REFERENCES}

1. Global Initiative for Chronic Obstructive Lung Disease. Gobal strategy for the diagnosis, management, and prevention of chronic obstructive pulmonary disease; 2018.

2. Oemiati. Kajian epidemiologis penyakit paru obstruktif kronik (PPOK). Media Litbangkes 2013;23:82-8.

3. Calverley PM, Stockley RA, Seemungal TA, Hagan G, Willits LR, Riley JH, Wedzicha JA. Investigating New Standards for Prophylaxis in Reduction of Exacerbations (INSPIRE) investigators: reported pneumonia in patients with COPD: findings from the INSPIRE study. Chest 2011;139:505-12.

4. Adil Shujaat, Ruth Minkin, Edward Eden. Pulmonary hypertension and chronic corpulmonale in COPD. Int J Chron Obstruct Pulmon Dis 2007;2:273-82.

5. Kurt B Stage, Thomas Middelboe, Tore B Stage, Claus H Sørensen. Depression in COPD-management and quality of life considerations. Int J Chron Obstruct Pulmon Dis 2006;1:315-20.

6. Perhimpunan Dokter Paru Indonesia. Penyakit Paru Obstruktif Kronik (PPOK): Pedoman Diagnosis and Penatalaksanaan Di Indonesia; 2011.

7. Mousing CA, Lomborg K. Self-care 3 mo after attending chronic obstructive pulmonary disease patient education: a qualitative descriptive analysis. Patient Prefer Adherence 2012;6:19-25.

8. Boven JFM Van. Medication monitoring and optimization: a targeted pharmacist program for the effective and costeffective improvement of chronic therapy adherence. J Managed Care Specialty Pharm 2014;20:786-92.

9. Bourbeau J, Ford G, Zackon H, Pinsky N, Lee J, Ruberto G. Impact on patients health status following early identification of COPD exacerbation. Eur Respir J 2007;30:907-13.

10. Lorig KR, Holman H. Self-management education: history, definition, outcomes, and mechanisms. Ann Behav Med 2003;26:1-7.

11. Harris M, Smith BJ, Veale A. Patient education programs-can they improve outcomes in COPD? Int J Chron Obstruct Pulmon Dis 2008;3:109-12.

12. Monninkhof EM, van der Valk PD, van der Palen J. Selfmanagement education for chronic obstructive pulmonary disease. Cochrane Database of Syst Rev 2004;CD002990.

13. Nguyen HQ, Fan VS, Herting J, Lee J, Fu M, Chen Z, et al. Patients with COPD with higher levels of anxiety are more physically active. Chest 2013;144:145-51.

14. Dabrowska EK. Telehealth in the UK: a critical perspective. Electronic J Business Res Methods 2003;2:37-46.

15. Tabak M, Brusse Keizer M, Valk $P$ Van Der, Hermens $H$, Vollenbroek M. A telehealth program for self-management of COPD exacerbations and promotion of an active lifestyle: a pilot randomized controlled trial. Int J COPD 2014;9:935-45.

16. Bentley CL, Mountain GA, Thompson J, Fitzsimmons DA, Lowrie $\mathrm{K}$, Parker SG, et al. A pilot randomized controlled trial of a telehealth intervention in patients with chronic obstructive pulmonary disease: challenges of clinician-led data collection. Trials 2014;15:313.

17. Udsen FW, Hejlesen O, Ehlers LH. A systematic review of the cost and cost-effectiveness of telehealth for patients suffering 
from chronic obstructive pulmonary disease. J Telemedicine Telecare 2014;20:212-20

18. Liu XL, Tan JY, Wang T, Zhang Q, Zhang M, Yao LQ, et al. Effectiveness of home-based pulmonary rehabilitation for patients with chronic obstructive pulmonary disease: a metaanalysis of randomized controlled trials. Rehabil Nurs 2014;39:36-59.

19. Patriani AA, Paramastri I, Priyanto MA. Pemberdayaan keluarga dalam rehabilitasi medik paru pada penderita penyakit paru obstruksi kronik di balai pengobatan penyakit paru-paru yogyakarta. Berita Kedokteran Masyarakat 2010;26:55-62.

20. Gill M. A national telehealth startegy for australia. In: Australian National Consultative Committee on Electronic Health; 2011.

21. Dyk L Van, Campus P, Africa S. A review of telehealth service implementation frameworks. Int J Environ Res Public Health 2014;11:1279-98.

22. Fairbrother P, Pinnock H, Hanley J, McCloughan L, Sheikh A, Pagliari C, et al. Exploring telemonitoring and self-management by the patient with chronic obstructive disease: a qualitative study embedded in a randomized controlled trial. Patient Education Counseling 2013;93,403-10.

23. Hailey BJ, Moss SB. Compliance behavior in patients undergoing hemodialysis: a review of the literature. Psychol Health Med 2000;5:395-406.

24. Lacasse Y, Goldstein R, Lasserson TJ, Martin S. Pulmonary rehabilitation for chronic obstructive pulmonary disease. Cochrane Database Syst Rev 2006;18:CD003793.
25. Stoilkova A, Janssen DJA, Wouters EFM. Educational programmes in COPD management interventions: a systematic review. Respiratory Med 2013;107:1637-50.

26. Wawandan Dewi. Pengetahuan, sikap, dan Perilaku Manusia. Yogyakarta: Nuha Medika; 2010.

27. Odili VU danOkoribe CO. Assessment of Pharmacists' knowledge on correct inhaler technique. Res J Pharm Biol Chem Sci 2010;1:768-72.

28. National Asthma Council Australia. Inhaler technique in adults with asthma or COPD (online); 2008. Available from: http://www.nationalasthma.org.au [Last accessed on 10 Jan 2019]

29. Lalani NS. A study of knowledge assessment and competence in asthma and inhaler technique of nurses employed at the university teaching hospital. Health 2012;3:16-8.

30. Lee SM, Chang YS, Kim CW, Kim TB, Kim SH, Kwon YE, et al. Skills in handling turbuhaler, diskus, and pressurized metereddose inhaler in korean asthmatic patients. Allergy Asthma Immunol Res 2011;3:46-52.

31. Scott RE, McCarthy FG, Jennett PA, Perverseff T, Lorenzetti D, Saeed A, et al. Telehealth outcomes: a synthesis of the literature and recommendations for uotcome indicators. J Telemed Telecare 2007;13(Suppl 2):1-38

32. Stellefson M, Chaney BH, Chaney JD. Examining the efficacy of DVD technology compared to print-based material in COPD self-management education of rural patients. Californian J Health Promot 2009;7:26-42.

33. Morgan DL. Focus groups as qualitative research. $2^{\text {nd }}$ edn Thousand Oaks, CA: Sage publications; 1997. 